\title{
Potential mycotoxin productivity of Alternaria alternata isolated from garden trees
}

\author{
Itsuki WATANABE ${ }^{* 1}$, Makoto KAKISHIMA*2, \\ Yoshikazu ADACHI ${ }^{* 1}$ and Hiromi NAKAJIMA ${ }^{* 1, * 3}$ \\ ${ }^{* 1}$ College of Agriculture, Ibaraki University, 3-21-1 Ami-machi, Ibaraki 300-0393, Japan \\ *2 Graduate School of Life and Environment Sciences University of Tsukuba, Tsukuba, Ibaraki 305-8572, Japan
}

\begin{abstract}
Summary
Potential mycotoxin productivity of Alternaria alternata isolated from leaves of Mube (Stauntonia hexaphylla), Hanamizuki (Cornus florida), and Kobushi (Magnolia praecocissima) was investigated with cultures growing on rice medium. By thin-layer chromatography and high-performance liquid chromatography, the presence of alternariol (AOH), alternariol monomethyl ether (AME), and altenuene (ALT) was confirmed in the rice culture extract. $A$. alternata isolate from Mube leaves produced AOH, AME, and ALT at concentrations of 22.99 $\mathrm{mg} / \mathrm{kg}, 9.13 \mathrm{mg} / \mathrm{kg}$, and $2.53 \mathrm{mg} / \mathrm{kg}$, respectively. A. alternata isolate from Hanamizuki leaves produced AOH, AME, and ALT at concentrations of $1.50 \mathrm{mg} / \mathrm{kg}, 0.59 \mathrm{mg} / \mathrm{kg}$, and $3.42 \mathrm{mg} / \mathrm{kg}$, respectively. A. alternata isolate from Kobushi leaves produced AOH, AME, and ALT at concentrations of $20.37 \mathrm{mg} / \mathrm{kg}, 0.95 \mathrm{mg} / \mathrm{kg}$, and $7.25 \mathrm{mg} / \mathrm{kg}$, respectively. These results suggested that $A$. alternata on garden trees contaminate food and feed with the mycotoxins.
\end{abstract}

Key words : Alternaria alternata, Alternaria mycotoxins, garden trees

(Received: June 24, 2006, Accepted: November 27, 2006)

\section{Introduction}

Fungi of the genus Alternaria are widely distributed in the environment and are commonly isolated from soil, living plants, decaying plant tissue and $\operatorname{food}^{11}$. Species in this genus include saprophytes and plant pathogens that are responsible for the spoilage of grain $^{2-4)}$, fruits ${ }^{5-8)}$ and vegetables $^{9)}$ as well as field crops of cereal.

Many Alternaria species including Alternaria alternata can produce several mycotoxins ${ }^{10)}$ that belong to three classes of compound: dibenzo- $\alpha$-pyrones derivatives (alternariol, $\mathrm{AOH}$; alternariol monomethyl ether, AME; and altenuene, ALT), tetramic acid derivatives (tenuazonic acid, TeA) and perylene derivatives (altertoxin I, ATX-I; and the related compounds altertoxins II and III). Alternaria mycotoxins have been detected at considerable concentrations in crops and fruits, crop and fruit products including apple juice and tomato products ${ }^{11-14)}$, and animal feed ${ }^{15)}$.

Alternaria mycotoxins exhibit toxicity to mammalian cells, bacteria and experimental animals ${ }^{10,16-27)}$. $\mathrm{AOH}, \mathrm{AME}$ and ATXs are mutagenic to bacteria ${ }^{19,21,23,25-27)}$ and mammalian cells ${ }^{17,28,29)}$, and AME and

\footnotetext{
${ }^{* 3}$ Correspond to: Hiromi NAKAJIMA (College of Agriculture, Ibaraki Univ.)
} 
TeA induced precancerous changes in the esophagus mucosa in mice ${ }^{24)}$. It is suspected that the metabolites of $A$. alternata are associated with human esophageal cancer ${ }^{28 \cdot 31}$.

There have been many studies of the mycotoxigenic characteristics of Alternaria species isolated from crops, but few studies of the incidence of Alternaria species in garden trees planted in residential areas and their potential mycotoxin productivity. Because garden trees are sometimes planted in gardens near human and animal houses, the presence of mycotoxigenic Alternaria species growing on garden trees may lead to spore dispersal from these trees and then to mycotoxin production in food or feed. The objectives of this study are therefore to determine the potential mycotoxin productivity of $A$. alternata isolated from garden trees planted in a residential area.

\section{Materials and methods}

Leaf samples and isolation of Alternaria Leaves of Mube (Japanese staunton vine) (Stauntonia hexaphylla) were collected in November, leaves of Hanamizuki (Dogwood) (Cornus florida) in September and leaves of Kobushi (Northern Japanese magnolia) (Magnolia praecocissima) in June and November (Table 1). All leaves were collected from the same trees, which grow in a garden of a residential area located in Tsukuba, Japan.

The leave segments of Mube, Hanamizuki and Kobushi were placed on $2 \%$ agar (Wako Pure Chemicals Industries Ltd., Japan) plates. The plates were incubated at room temperature $\left(22-25{ }^{\circ} \mathrm{C}\right)$ for 5-7 days. They were observed under a stereomicroscope, and spores of Alternaria growing from the leaf surface were transferred to a corn meal agar (Nissui, Tokyo, Japan) slant and incubated at room temperature $\left(22-25{ }^{\circ} \mathrm{C}\right)$ for 5-7 days. Then, single-spore isolation was performed to establish isolates of Alternaria with $2 \%$ agar plates, and these isolates were maintained on a corn meal agar medium at room temperature $\left(22-25{ }^{\circ} \mathrm{C}\right)$ for morphological examination and metabolite profiling. Thirteen isolates, comprising 3 isolates from different colonies from leaves of Mube, and 4 and 6

Table 1. Origins, isolate numbers, collection months and mycotoxin productivities of $A$. alternata isolates studied.

\begin{tabular}{|c|c|c|c|c|c|}
\hline \multirow{2}{*}{ Isolate } & \multirow[b]{2}{*}{ Month collected } & \multirow{2}{*}{ Origin } & \multicolumn{3}{|c|}{ Mycotoxin productivity } \\
\hline & & & $\mathrm{AOH}$ & $\mathrm{AME}$ & ALT \\
\hline M-1 & November & Mube & + & + & + \\
\hline M-2 & November & Mube & + & + & + \\
\hline M-3 & November & Mube & + & + & + \\
\hline $\mathrm{H}-1$ & September & Hanamizuki & + & + & + \\
\hline $\mathrm{H}-2$ & September & Hanamizuki & + & + & + \\
\hline $\mathrm{H}-3$ & September & Hanamizuki & + & + & + \\
\hline $\mathrm{H}-4$ & September & Hanamizuki & + & + & + \\
\hline $\mathrm{K}-1-1$ & June & Kobushi & + & + & + \\
\hline $\mathrm{K}-2-1$ & November & Kobushi & + & + & + \\
\hline $\mathrm{K}-2-2$ & November & Kobushi & + & + & + \\
\hline $\mathrm{K}-2-3$ & November & Kobushi & + & + & + \\
\hline $\mathrm{K}-2-4$ & November & Kobushi & + & + & + \\
\hline $\mathrm{K}-2-5$ & November & Kobushi & + & + & + \\
\hline
\end{tabular}

AOH: alternariol, AME: alternariol monomethyl ether, ALT: altenuene 
isolates from Hanamizuki and Kobushi, respectively, were selected and used in this study. For light microscopic morphological examination of hyphae and spores, these specimens were prepared with a $0.15 \%$ aqueous gelatin solution or lactic phenol solution. Their sporulation pattern cultured on a corn meal agar for 7-14 days was observed with a stereomicroscope.

Culture conditions and extraction procedure For the examination of AOH, AME and ALT productivities of Alternaria isolates, each isolate was inoculated into $50 \mathrm{~g}$ of milled rice which had been moistened with $25 \mathrm{ml}$ of water after soaked in water for 1 hour and autoclaved for $20 \mathrm{~min}$ at 121 ${ }^{\circ} \mathrm{C}$, and incubated at room temperature $\left(22-25{ }^{\circ} \mathrm{C}\right)$ for 21 days. To obtain a crude rice culture extract, the medium was homogenized with a spatula in $100 \mathrm{ml}$ of methanol, extracted by soaking overnight with the methanol, and then filtered through filter paper (Advantec, Tokyo, Japan). The residues were re-extracted twice with $50 \mathrm{ml}$ of methanol and filtered again. The combined methanol extract was mixed with $200 \mathrm{ml}$ of $20 \%$ ammonium sulfate in a separatory funnel and then filtered. The filtrate was transferred to another separatory funnel and extracted three times with $100 \mathrm{ml}$ of chloroform. The combined chloroform extract was dried over anhydrous sodium sulfate and evaporated to near dryness using a rotary evaporator at $40{ }^{\circ} \mathrm{C}$, and then, completely dried under a stream of nitrogen gas. The resulting residue was dissolved in $3 \mathrm{ml}$ of methanol. The sample solution was analyzed for $\mathrm{AOH}, \mathrm{AME}$ and ALT by thin-layer chromatography (TLC). Ten-fold dilutions of the sample solution were prepared for high-performance liquid chromatography (HPLC).

TLC The rice culture extracts were screened for AOH, AME, and ALT using a precoated silica gel TLC plate (silica gel 60 F254 Merck Ltd. Japan) by comparing the rate of flow (Rf) values of these mycotoxins with those standards. The solvent systems was toluene:ethyl acetate: formic acid (50:40:10, v/v/v) according to Seitz et al. ${ }^{32)}$, and detected under UV light at a wavelength of $365 \mathrm{~nm}$.

HPLC Analysis was performed using a Shimadzu LC-6A HPLC system equipped with a Shimadzu SCL-6A system controller, a Shimadzu SCL-6A pump, a Shimadzu SPD-6A UV detector, and a Shimadzu C-R3A integrator. The rice extracts were applied to a Phenomenex column (Prodigy ODS-3, $4.6 \mathrm{~mm}$ I.D. $\times 25 \mathrm{~cm}, 5 \mu \mathrm{m}$ particle size, Shimadzu, Japan) with an ODS $3.0 \mathrm{~mm}$ I.D. $\times 4.0 \mathrm{~mm}$ Phenomenex guard cartridge column (Shimadzu, Japan) thermostatted at $30{ }^{\circ} \mathrm{C}$ in an oven (Shodex oven AO-30). The mobile phase was methanol: water $(80: 20, \mathrm{v} / \mathrm{v})$ at a flow rate of $0.4 \mathrm{ml} / \mathrm{min}$. Detection was performed at a wavelength of $260 \mathrm{~nm}$, and $10 \mu \mathrm{L}$ of a sample was injected by a Rheodyne7125 injector.

The peak area of the extract of the toxin was quantitatively determined by comparing it with the peak area of a standard toxin of known concentration. The recovery of AOH, AME and ALT were 81 $\%, 81 \%$, and $88 \%$, respectively, from $50 \mathrm{~g}$ of rice culture spiking at a concentration of $0.5 \mathrm{mg} / \mathrm{kg}$ for each toxin. No AOH, AME and ALT were recovered from non-spiked rice culture.

Reagents Standard Alternaria mycotoxins including AOH, AME, and ALT were purchased from Sigma Co., Ltd., USA. The reagent-grade solvents used for TLC and the HPLC-grade solvents used for HPLC were purchased from Wako Pure Chemicals Industries Ltd., Japan.

\section{Results and discussion}

All the thirteen Alternaria isolates from the leaves of Mube, Hanamizuki and Kobushi were morphologically identified as A. alternata, and the results of TLC demonstrated that all the isolates of 
A. alternata produced $\mathrm{AOH}, \mathrm{AME}$ and ALT in the rice culture with some different characteristics in terms of the productivities of the metabolites.

Spores of an isolate grown on a corn meal agar are shown in Fig. 1. All isolates from Mube, Hanamizuki and Kobushi produced non-beaked conidia, with were ovoid or obclavate, pale brown to brown, usually branched and found in moderately long chains (approximately 4-10 spores). They exhibited the typical characteristics of A. alternata, as defined in the literature ${ }^{33)}$.

In our experiment, all the thirteen isolates of $A$. alternata produced $\mathrm{AOH}, \mathrm{AME}$ and ALT during growth in the rice culture similarly to the isolates in other studies that were isolated from maize, oilseed and wheat ${ }^{2-434,35)}$. Result of the TLC of rice culture extracts (Fig. 2) demonstrated that AOH (Rf,

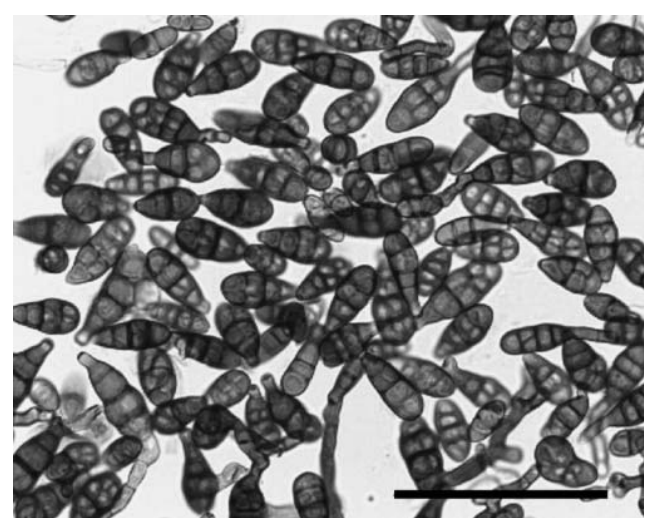

Fig. 1. Morphology of A. alternata spores produced on corn meal agar. Spores of Hanamizuki isolate (H-4). Bar $=100 \mu \mathrm{m}$

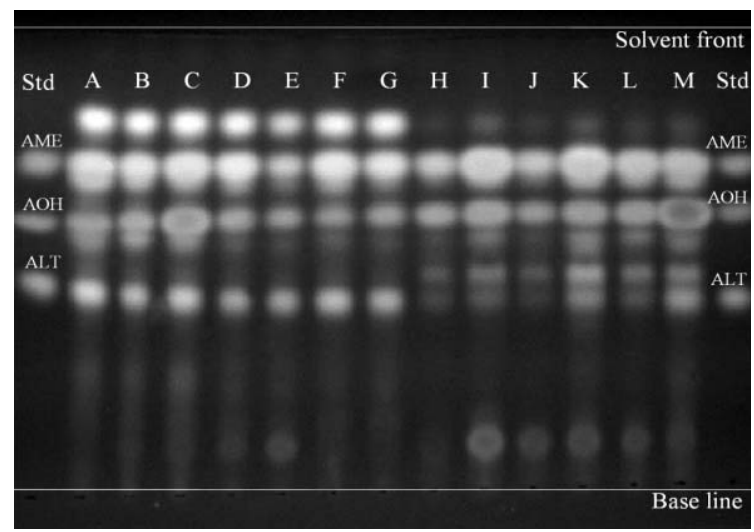

Fig. 2. TLC of extracts from rice culture inoculated with each isolate and standard Alternaria mycotoxins, namely, $\operatorname{AOH}(0.2 \mu \mathrm{g}), \operatorname{AME}(0.2 \mu \mathrm{g})$ and $\operatorname{ALT}(0.2 \mu \mathrm{g})$. AOH, AME and ALT were produced by all A. alternata isolates. Std, standard of Alternaria mycotoxins. A, B and $\mathrm{C}$ are extracts from the rice culture inoculated with $M u b e$ isolates of M-1, M-2 and M-3, respectively. D, E, F and G are extracts from the rice culture inoculated with Hanamizuki isolates of H-1, H-2, H-3, H-4, respectively. H, I, J, K, L and M are extracts from rice culture inoculated with Kobush $i$ isolates of K-1-1, K-2-1, K-2-2, K-2-3, K-2-4 and $\mathrm{K}-2-5$, respectively. 
0.59) and AME (Rf, 0.72) were detected as blue-fluorescence spots and ALT (Rf, 0.40) was detected as a greenish-blue fluorescence spot under UV light at a wavelength of $365 \mathrm{~nm}$. Three Alternaria isolates randomly selected from each tree isolate were quantitatively analyzed by HPLC. HPLC profiles of rice culture extracts from the three selected isolates are shown in Fig. 3. The peaks of AOH, AME and ALT appeared with retention times of $9.4,15.4$ and $7.7 \mathrm{~min}$, respectively. The concentrations of Alternaria toxins in the rice culture are shown in Table 2. A. alternata isolate from Mube (M-2) had the ability to produce AOH, AME, and ALT at concentrations of $22.99 \mathrm{mg} / \mathrm{kg}, 9.13 \mathrm{mg} / \mathrm{kg}$, and 2.53
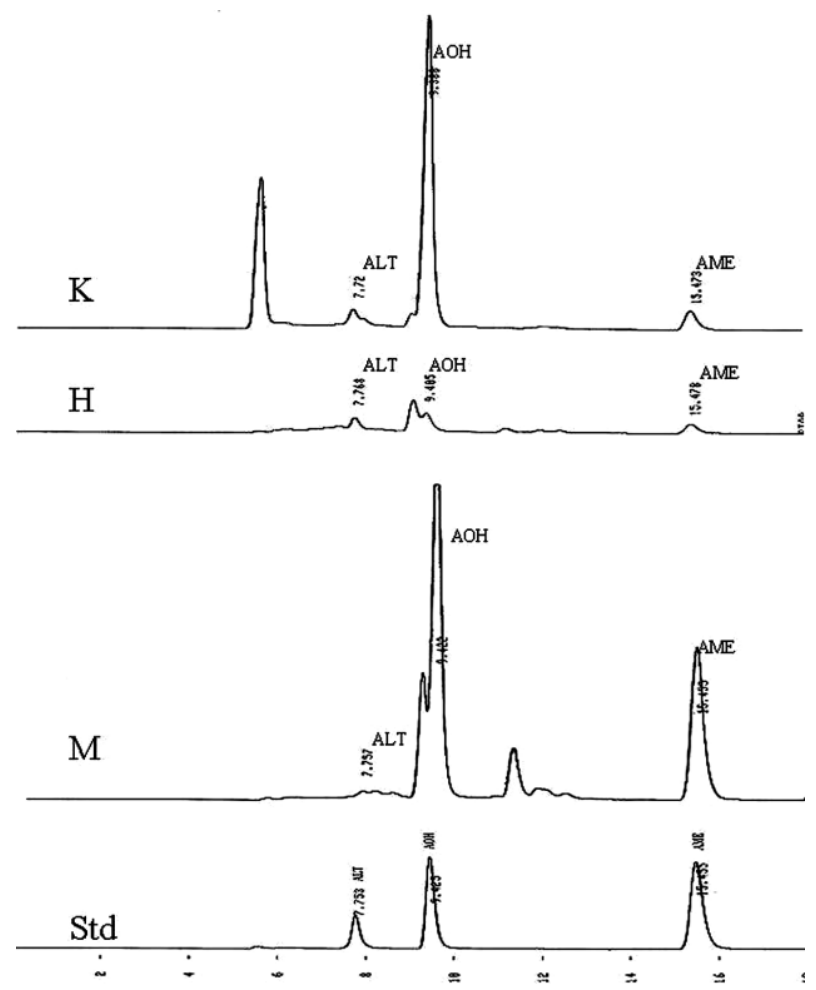

Fig. 3. HPLC profiles of rice culture extracts of A. alternata isolated from Mube, Hanamizuki and Kobushi, and standard Alternaria mycotoxins, namely, AOH $(0.1 \mathrm{mg} / \mathrm{L}), \mathrm{AME}(0.1$ $\mathrm{mg} / \mathrm{L})$, and ALT $(0.1 \mathrm{mg} / \mathrm{L})$. AOH, AME and ALT were detected in the extracts. Std, standard of Alternaria mycotoxins; M, extract from rice culture inoculated with $A$. alternata isolated from Mube (M-2); $\mathrm{H}$, extract from rice culture inoculated with $A$. alternata isolated from Hanamizuki (H-4); K, extract from rice culture inoculated with A. alternata isolated from Kobushi (K-1-1).

Table 2. Toxin productions by A. alternata isolate in rice culture.

\begin{tabular}{crrrr}
\hline \multirow{2}{*}{$\begin{array}{c}\text { Isolates } \\
\text { analyzed }\end{array}$} & \multicolumn{3}{c}{ Toxin content $(\mathrm{mg} / \mathrm{kg})$} & \multirow{2}{*}{ Origin } \\
\cline { 2 - 4 } & $\mathrm{AOH}$ & AME & ALT & \\
\hline M-2 & 22.99 & 9.13 & 2.53 & Mube \\
H-4 & 1.50 & 0.59 & 3.42 & Hanamizuki \\
K-1-1 & 20.37 & 0.95 & 7.25 & Kobushi \\
\hline
\end{tabular}


$\mathrm{mg} / \mathrm{kg}$, respectively. A. alternata isolate from Hanamizuki (H-4) produced AOH, AME, and ALT at concentrations of $1.50 \mathrm{mg} / \mathrm{kg}, 0.59 \mathrm{mg} / \mathrm{kg}$, and $3.42 \mathrm{mg} / \mathrm{kg}$, respectively. A. alternata isolate from Kobushi (K-1-1) produced AOH, AME, and ALT at concentrations of $20.37 \mathrm{mg} / \mathrm{kg}, 0.95 \mathrm{mg} / \mathrm{kg}$, and $7.25 \mathrm{mg} / \mathrm{kg}$, respectively. The production of the toxins in the rice culture resulted in a lower AME concentration than the AOH concentration, and this was similar to the results of previous studies ${ }^{2,434,35)}$.

These results indicate that the leaves of Mube, Hanamizuki and Kobushi are habitats of mycotoxigenic $A$. alternata. These results suggested that $A$. alternata on garden trees contaminate food and feed with the mycotoxins.

\section{References}

1 ) Rotem, J.: The Genus Alternaria, Biology, Epidemiology, and Pathogenicity, (1994), APS Press, St. Paul, $\mathrm{MN}$.

2 ) Logrieco, A., Bottalico, A., Solfrizzo, M. Mule, G.: Mycologia, 82, 501-505 (1990)

3 ) Li, FQ., Toyazaki, N., Yoshizawa, T.: J. Food Prot., 64, 567-571 (2001)

4 ) Torres, A., Gonzalez, H.H., Etcheverry, M., Resnik, S.L., Chulze, S.: Food Addit. Contam., 15, 56-60 (1998)

5 ) Grogan, R., Kimble, K., Misaghi, I.: Phytopathol., 65, 880-886 (1975)

6 ) Mislivec, P.B., Bruce, V.R., Stack, M.E., Bandler, R.J.: J. Food Prot., 50, 38-41 (1987)

7 ) Filajdic, N., Sutton, T.B.: Plant. Dis., 75, 1045-1048 (1991)

8 ) Stinson, E.E., Bills, D.D., Osman, S.F., Siciliano, J., Ceponis, M.J., Heisler, E.G.: J. Agric. Food Chem., 28, 960-963 (1980)

9 ) Pryor, B., Strandberg, J., Davis, R., Nunez, J., Gilbertson, R.: Plant Dis., 86, 1115-1122 (2002)

10) Harvan, D.J. Pero, R.W.: "Mycotoxins and Other Fungal Related Food Problems" (ed. Rodricks J. V.), pp.344-355 (1976), American Chemical Society, Washington DC.

11) Delgado, T., Gomez-Cordoves, C.: J. Chromatogr. A, 815, 93-97 (1998)

12) Scott, P.M.: J. AOAC Int., 84, 1809-1817 (2001)

13) Motta, S.D., Valente Soares, L.M.: Food Addit. Contam., 18, 630-634 (2001)

14) Drusch, S., Ragab, W.: J. Food Prot., 66, 1514-1527 (2003)

15) Nawaz, S., Scudamore, K.A., Rainbird, S.C.: Food Addit. Contam., 14, 249-262 (1997)

16) Pero, R.W., Owens, R.G., Dale, S.W., Harvan, D.: Biochim. Biophys. Acta, 230, 170-179 (1971)

17) Pero, R.W., Posner, H., Blois, M., Harvan, D., Spalding, J.W.: Environ. Health Perspect., 4, 87-94 (1973)

18) Sauer, D.B., Seitz, L.M., Burroughs, R., Mohr, H.E., West, J.L., Milleret, R.J., Anthony, H.D.: J. Agric. Food Chem., 26, 1380-1393 (1978)

19) Scott, P.M., Stoltz, D.R.: Mutat. Res., 78, 33-40 (1980)

20) Pollock, G.A., DiSabatino, C.E., Heimsch, R.C., Hilbelink, D.R.: Food Chem. Toxicol, 20, 899-902 (1982)

21) Stack, M.E., Prival, M.J.: Appl. Environ. Microbiol., 52, 718-722 (1986)

22) Woody, M.A., Chu, F.S.: "Alternaria Biology, Plant Diseases and Metabolites" (eds. Chelkowski J., Visconti A.), pp.409-434 (1992), Elsevier, Amsterdam.

23) Schrader, T.J., Cherry, W., Soper, K., Langlois, I., Vijay, H.M.: Teratog. Carcinog. Mutagen, 21, 261-274 (2001)

24) Yekeler, H., Bitmis, K., Ozcelik, N., Doymaz, M.Z., Calta, M.: Toxicol. Pathol., 29, 492-497 (2001) 
25) Brugger, E.M., Wagner, J., Schumacher, D.M., Koch, K., Podlech, J., Metzler, M., Lehmann, L.: Toxicol. Lett., 164, 221-230 (2006)

26) Lehmann, L., Wagner, J., Metzler, M.: Food Chem. Toxicol., 44, 398-408 (2006)

27) Schrader, T.J., Cherry, W., Soper, K., Langlois, I.: Mutat. Res., 606, $61-71$ (2006)

28) Liu, G.T., Qian, Y.Z., Zhang, P., Dong, W.H., Qi, Y.M., Guo, H.T.: Chin. Med. J. (Engl), 105, 394-400 (1992)

29) Dong, Z.G., Liu, G.T., Dong, Z.M., Qian, Y.Z., An, Y.H., Miao, J.A., Zhen, Y.Z.: Carcinogenesis, 8, 989-991 (1987)

30) Zhen, Y.Z., Xu, Y.M., Liu, G.T., Miao, J., Xing, Y.D., Zheng, Q. L., Ma, Y.F., Su, T., Wang, X.L., Ruan, L.R., Tian, J.F., Zhou, G., Yang, S.L.: IARC Sci. Publ., 253-257 (1991)

31) Liu, G.T., Qian, Y.Z., Zhang, P., Dong, Z.M., Shi, Z.Y., Zhen, Y.Z., Miao, J., Xu, Y.M.: IARC Sci. Publ., 258$262(1991)$

32) Seitz, L.M., Sauer, D.B., Monr, H.E., Burroughs, R., Paukstelis, J.V.: J. Agric. Food Chem., 23, 1-4 (1975)

33) Simmons, E.G.: “Alternaria: Biology, Plant Disease and Metabolites” (eds. Chelkowski J., Visconti A.), pp.1-36 (1992), Elsevier, Amsterdam.

34) Visconti, A., Sibilia, A., Sabia, C.: Mycotoxin Res., 8, 9-16 (1992)

35) Zajkwski, P., Grabarkiewicz-Szczesna, J., Schmidt, R.: Mycotoxin Res., 7, 11-15 (1991)

\section{庭木から分離した Alternaria alternata のマイコトキシン産生能}

渡辺 樹, 足立吉數, 中島弘美：茨城大学農学部（300-0393 茨城県稲敷郡阿見町中央 3-21-1)

杮嶌 眞: 筑波大学生命環境科学研究科 (305-8572 茨城県つくば市)

ムベ, ハナミズキ抽よ゙コブシの葉から分離した Alternaria alternata の米培地上でのマイコトキシン産生 能を調査した。薄層クロマトグラフィーと高速液体クロマトグラフィーにより，アルタナリオール，アルタ ナリオールモノメチルエーテル,アルタヌエンが米培地抽出物中に確認された. ムべから分離した A alternata は米培地上でAOH，AME， およびALTをそれぞれ $22.99 \mathrm{mg} / \mathrm{kg}, 9.13 \mathrm{mg} / \mathrm{kg}$, および $2.53 \mathrm{mg} / \mathrm{kg}$ 産生 していた。ハナミズキの葉から分離したA. alternata は米培地上でAOH，AME，およびALTをそれぞれ $1.50 \mathrm{mg} / \mathrm{kg}, 0.59 \mathrm{mg} / \mathrm{kg}$, and $3.42 \mathrm{mg} / \mathrm{kg}$ 産生していた。コブシの葉から分離したA. alternata は米培地 上で AOH，AME，およびALTをそれぞれ $20.37 \mathrm{mg} / \mathrm{kg}, 0.95 \mathrm{mg} / \mathrm{kg}$ ，および $7.25 \mathrm{mg} / \mathrm{kg}$ 産生していた。 これらの結果は庭木由来の A. alternata が食物および飼料をマイコトキシンで污染することを示唆している。

キーワード : Alternaria, Alternaria マイコトキシン , 庭木 